\title{
OS ESTADOS LIMÍTROFES E SEUS TRAÇOS DE PERSONALIDADE PSICÓTICA: ANALISANDO OS SINTOMAS EM UM ESTUDO DE CASO
}

\section{Lucas Tadeu Rezende ${ }^{1}$}

Resumo: Os estados limítrofes se acham circunscritos economicamente como organizações autônomas e distintas, ao mesmo tempo das neuroses e das psicoses. Os pacientes com transtorno de personalidade Borderline se caracterizam por afetos, humor, comportamento, relações objetais e auto-imagem extraordinariamente instáveis. Eles podem ser querelantes em um momento, depressivos no seguinte e mais tarde se queixar de que não têm sentimentos. Podem ter episódios psicóticos de curta duração, em vez de surtos plenos, e os sintomas psicóticos são quase sempre circunscritos, fugazes e duvidosos. Possibilitou-se uma visão panorâmica acerca dos traços psicóticos existentes no Transtorno de Personalidade Borderline; Aparentam ser de certa maneira aquilo que o Jung nos ensinou sobre os estados alucinatórios, onde o indivíduo concentra sua atenção em um "elemento atormentador externo" e não somente em uma realidade complexa em que somente o paciente vê, onde o delírio possibilita essa fuga a aquele acometido pela doença.

Palavras-chave: Paciente Borderline; Psicose e Borderline; Psicanálise e Borderline; Sofrimento psíquico; Manejo Clínico.

\footnotetext{
${ }^{1}$ Casa da Enfermagem, R: Anésia Nunes Matarazzo, 113 - Vila Rubi - São José dos Campos /SP, Brasil. E-mail: lucas.nacional@hotmail.com.
} 